\title{
Embracing values? The question of Finnish membership of the Council of Europe as a case of political value deliberation in European integration, 1987-1989
}

\section{Tеeти HÄKKINEN}

Understanding of values has played a significant role throughout the European integration project. ${ }^{1}$ Under pressure from both economic and foreign crises, contemporary Europe continues to experience difficulties regarding the comprehension and implementation of generally accepted values in daily political life. Such difficulties are not, however, new and can be approached through useful historical case studies. Finland's entry to the Council of Europe in 1989 as the last country outside the Soviet European hemisphere has received relatively little academic attention, despite its usefulness as a case illustrating how nations fully or partially under Soviet influence began to draw closer in their relations to Western value understanding. The topic is naturally mentioned, but seen as a part of the wider process of Finland consolidating its relations to the political and economic integration of Europe; ${ }^{2}$ the history of Finnish foreign policy has generally been broadly studied, or has focused specifically on the media. ${ }^{3}$ Jorma Kallenautio has suggested that the Finnish entry into the Council of Europe was a highly significant affair; not only did Finland for the first time enter, in addition to certain United Nations conventions, into a binding treaty on international legislation, but this was also carried out with reduced procedural process, thereby creating a precedent for further entries into international organisations and especially to the European Union. ${ }^{4}$ However, it is interesting how even Finnish foreign policy scholars have tended to forget both the part played by the presidential elections in the Finnish application process and how the entry was, above all, about embracing Western European core values.

Values are a logical way to grasp the ideological discussion since, as the argument goes, the Western international community is based on liberal political values such as human rights, civil liberties and political rights. As a result, only a state basing its political system on these rights and following the rules and norms can gain acceptance

1. This research was supported by the Academy of Finland, project Supra- and Transnational Foreign Policy versus National Parliamentary Government, 1914-2014. [Decision no.275589].

2. O. JUSSILA, S. HENTILÄ, J. NEVAKIVI, Suomen Poliittinen Historia 1809-2009, WSOY, Helsinki, 2009(6), p.364; J. SUOMI, Kohti Sinipunaa. Mauno Koiviston Aika 1986-1987, Otava, Helsinki, 2008, p.336.

3. R. KULLAA, Non-alignment and its Origins in Cold War Europe. Yugoslavia, Finland and the Soviet Challenge, I.B. Tauris, London and New York, 2012; J. MEHTIÖ J, Kun Kaikki Halusivat Strasbourgiin - Suomen Liittyminen Euroopan Neuvostoon 1989, in: L. CLERC, T. LINTUNEN (eds), Suomen Asialla? Yksityiset ja Julkiset Toimijat Kansainvälisessä Yhteistyössä, Ajankohta 2013, Pallosalama, Turku, 2013, pp.213-236, here p.213 f.

4. J. KALLENAUTIO, Suomi Kylmän Rauhan Maailmassa. Suomen Ulkopolitiikka Porkkalan Palautuksesta 1955 Euroopan Unionin Jäsenyyteen 1995, Suomen Kirjallisuuden Seura, Helsinki, 2005, pp.462-465. 
in the eyes of this community, practically socialising it into the institution. As such, the key values the Council represented even provide the definition of a rightful state from a European point of view and which are essentially the issues promoted to nonmember states of such a community. ${ }^{5}$ However, as Teija Tiilikainen has argued, even the underlying idea of European integration contrasts with the various distinct political traditions of Europe which understand the political role of the individual and the state differently; for instance in the Finnish case, the approach to European integration was heavily state-oriented, as was the Finnish tradition in foreign policy decisionmaking. ${ }^{6}$ In the subsequent development, membership in the Council of Europe is seen as a sign of approval of the Western community before any membership of major organisations, such as NATO and the European Union. ${ }^{7}$

This article sheds light on how the values of the Council of Europe, probably one of the most value-oriented international organisations in Europe, were discussed in the Finnish political landscape when the Finnish entry to the organisation became a topical issue, and also examines the response of the Parliamentary Assembly of the Council of Europe.

All in all, this qualitative approach is expected to provide an answer to the question of the extent to which the Finnish value-related political discussion was influenced by the domestic political culture and its topical issues, and to reveal national distinctions in the discussion. By so doing, one historical and national empirical case study can help to explain the complexity of a decision to join an international organisation in an era of polarised international relations. The values of the Council of Europe originate from its statute, adopted in 1949, of the organisation promoting 'individual freedom, political liberty and the rule of law, principles which form the basis of all genuine democracy'. ${ }^{8}$ When joining the Council, Finland had to define its own relationship to the statute of the organisation. As such, in this paper the qualitative approach emphasized the referring to the concepts of freedom, liberty, democracy and also sovereignty as parts of the political argumentation and value-oriented discussion. By pursuing the analytical approach described, the attention turned to the national discursive struggle as to how membership is interpreted and explained and subsequently transformed as a new narrative on the national foreign policy approach; the discursive approach has gained more attention as a way to explain the national po-

5. C. REUS-SMIT, The Constitutional Structure of International Society and the Nature of Fundamental Institutions, in: International Organization 4(1997), pp.555-589; F. SCHIMMELFENNIG, S. ENGERT, H. KNOBEL, European Socialization Agencies and Strategies, in: F. SCHIMMELFENNIG, S. ENGERT, H. KNOBEL (eds), International Socialization in Europe. European Organizations, Political Conditionality and Democratic Change, Palgrave Macmillan, Basingstoke, 2006, pp.27-56, here pp.27-28.

6. T. TIILIKAINEN, Europe and Finland. Defining the Political Identity of Finland in Western Europe, Ashgate, Aldershot, 1998, pp.52-54, 158-159.

7. F. SCHIMMELFENNIG et al., op.cit., p.35.

8. EDUSKUNTA, Asiakirjat A1. Hallituksen esitykset 1-105. Valtiopäivät 1989, Valtion painatuskeskus, Helsinki, 1989, HE no: 17: p.15. 
litical conceptualisation of European integration as well as to analyse the possibilities of the discursive context. ${ }^{9}$

The source material used features four contrasting main types of historical records: the archives of the ministry of Foreign Affairs (AMFA in references) dealing with the membership discussion and thus providing a number of reports, letters, memoranda and minutes of officials within the ministry, the debates and parliamentary papers of the Parliament of Finland, eduskunta, the debates of the Parliamentary Assembly of the Council of Europe and finally the writing in the printed news media; these sources are critically examined in order to pinpoint value-related commentary and discussion of different key political individuals and groups. After the introduction, the focus turns to the ministry of Foreign Affairs and to its value deliberations.

\section{The longer perspective on the rush to Strasbourg in 1987-1988}

Despite its manifestations as a supporter of pluralism and democracy, during the Cold War period Finland leaned somewhat to the East in foreign policy. The key reason for such a foreign policy approach was the Agreement of Friendship, Cooperation, and Mutual Assistance (YYA Treaty) with the Soviet Union, the agreement that had influenced the Finnish foreign policy agenda since 1948 and which was rhetorically frequently emphasized and referred to in different Finnish political forums; certain publicly presented ideas, such as proposals to improve relations to certain Western international organisations could meet with a critical reaction and arguments of antiSovietism. The Finnish domestic political sphere emphasized and implemented multiparty democracy, but the exercise of foreign policy remained a politically sensitive issue, mainly reserved for the President of the Republic due to experiences of the first decades of the Cold War. Urho Kekkonen, President of Finland (1956-1981), had been able to create good personal relations with the Soviet Union and was instrumental in the formation of different governments through his extensive constitutional powers. Similarly, the exercise of foreign policy had originally been constitutionally assigned to the President and this orientation was reinforced during the Cold War years, with different governments accepting a specific orientation in foreign policy specifically intended to keep Finland out of trouble in her foreign policy. The policy of non-alignment and maintaining a neutral position was a way to distance Finland from the polarised relations of the rival blocs, but the existence of the Agreement

9. T. DIEZ, Europe as a Discursive Battleground: Discourse Analysis and European Integration Studies, in: Cooperation and Conflict, 1(2001), pp.5-38; H. LARSEN, Normative Power Europe and the Importance of Discursive Context. The European Union and the Politics of Religion, in: Cooperation and Conflict, 4(2014), pp.419-437; T. SAARINEN, P. IHALAINEN, M. HALONEN, Diverse Discourses in Time and Space: Historical, Discourse Analytical and Ethnographic Approaches to Multi-sited Language Policy Discourse, in: T. SAARINEN, P. IHALAINEN, M. HALONEN (eds), Language Policies in Finland and Sweden. Interdisciplinary and Multi-sited Comparisons, Multilingual Matters, Bristol, 2015, pp.3-26, here p.4f. 
efficiently limited interest in seeking modes of co-operation with the West which the Soviet Union might consider hostile.

The accession to the Council of Europe formed one example of a potentially dangerous political manoeuvre. In 1986 the Soviet Ambassador had warned the Finnish government of the potential effect of membership on neutrality, since the Council of Europe had originally been geared towards the communist ideology..$^{10}$ If the Soviet Union were to reject membership, the implications could be significant. A similar idea had been behind the fact that Finland had not applied for membership during the early years of the Council. The YYA Treaty dated back to 1948, the same year when the key events leading to the establishment of the Council of Europe had taken place. For instance, in Britain the different forms of 'Western Union' had been envisaged to provide co-operation between countries creating a geographical and mental barrier against Communism and thus helping to protect Western civilisation, predominantly a value system supporting individual rights and multiparty democracy. ${ }^{11}$ In 1948, the future of Finland was more or less linked to the further development of Finnish-Soviet relations. With the Soviets critically disposed towards the Council of Europe, it was no wonder that Finland did not even attempt to join. Times changed, but it took a considerable amount of time. The Council of Europe was no exception as an organisation the Soviets considered too Western; the Finnish membership accession process of 1958 to join the OEEC was buried for similar reasons. NORDEK, a joint Nordic effort to create economic co-operation, was likewise turned down in Finland in early 1970 due to its close contacts with the EEC, an organisation the Soviets despised. ${ }^{12}$ The process of joining the Council of Europe was related to economic issues, but it was predominantly a straightforward matter of taking a major ideological step towards the West.

In 1987 Finnish membership of the Council of Europe had for some time been an occasional topic in Finnish political discussions. Finland had traditionally refrained from entering any such international organisation that could weaken its militarily non-aligned and politically neutral international position, a position it considered extremely important for its foreign policy approach. This policy was dictated mainly by the presidency given his position as leader of foreign policy. ${ }^{13}$ This traditional approach to Western European international organisations, on the other hand, had already begun to crumble.

Despite the cautious foreign policy approach, Finland had not totally distanced itself from the Council. For instance, its parliamentarians had participated as obser-

10. AMFA [Archives of the Ministry of Foreign Affairs Finland], Box EN 13.0 I, P.M. No.16, 09.01.1986.

11. The National Archives of the United Kingdom, Box CAB 129/23/6, CP (48) 6, 04.01.1948.

12. J. AUNESLUOMA, Vapaakaupan Tiellä. Suomen Kauppa- ja integraatiopolitiikka Maailmansodista EU-aikaan, SKS, Helsinki, 2011, pp.171-172 and 231-239.

13. See N. GÖTZ, Finlandization, in: S.C. TUCKER (ed.) Encyclopedia of the Cold War. A Political, Social, and Military History, vol.2, ABC-CLIO, Santa Barbara, 2008, p.459; R. VÄYRYNEN, Finlandization: From Deterrence to Confidence, in: K. KILJUNEN, F. SUNDMAN, I. TAIPALE (eds), Finnish Peace Making, Suomen rauhanliitto \& YK-yhdistys, Helsinki, 1987, pp.173-198. 
vers in the sessions of the Parliamentary Assembly since 1963. At that time, however, it was perceived in the government that membership could have an undesirable effect on the Finnish foreign policy position. In 1976 the ministry of Foreign Affairs reevaluated the matter and found the Council to be free from conflicts of interest between super powers; as such, no obstacles were seen to Finnish membership, but the political will to apply for membership was lacking and the traditional policy was continued. A few years later, in 1982, membership was again discussed both in Parliament (eduskunta) and the government. President Mauno Koivisto, however, was not yet ready to embrace membership at the time. ${ }^{14}$

In the 1980s the political and economic integration of Western Europe confronted Finland with the question to what extent Finland should follow the development within Europe; standing aside was not considered a good option. ${ }^{15}$ It is important to remember that in the latter part of the 1980s Finland was struggling with its increasing trade deficit; the Soviet trade had experienced a significant reduction and Finland needed to create new export opportunities. Jorma Kallenautio argues that this worked as a key catalyst for Finnish re-evaluation of Western European integration, a process that was, according to Juhana Aunesluoma, dominated by pragmatism. ${ }^{16}$ As a sign of the changing times, Finland had become a full member of the European Free Trade Association (EFTA) in 1986, representing a more difficult part in the Finnish reorientation towards Western Europe. Finland had been an associate member of EFTA since 1961, through the FINEFTA agreement. That early step towards Western economies had likewise been influenced by relations with the Soviet Union, as the Eastern superpower had initially been rather reluctant to approve such a free trade treaty without the Soviet Union having a similar arrangement with Finland. Through personal relations between the Finnish and Soviet leaders the Finnish interest in strengthening its economy was eventually approved. In the early 1980s full membership in EFTA was achieved with rather little advance consultation with the Soviet Union. This was less related to a different foreign policy approach and more to a simple expectation; the Finnish position in EFTA was unlikely to change dramatically with full membership. ${ }^{17}$ Membership of the Council of Europe represented a softer issue in terms of foreign policy tradition. EFTA represented economic connections, unlike the Council of Europe, which featured potential changes in other areas within the Finnish legislation. This would manifest itself in the political discussion.

If the Council of Europe had been an occasional topic in politics, it seemed to continue on the same path when the issue re-emerged in spring 1987 briefly in Parliament. The failed motion was followed by a publicly widely noted call for membership from the CEO of the then major company, Nokia. The press was cautiously

14. AMFA, Box 32.00 EN I, Kahiluoto, 16.02.1988.

15. M. JAKOBSON, Suomen on lunastettava paikkansa Euroopassa, in: Suomen Kuvalehti, 27.03.1987, pp.70-73.

16. J. KALLENAUTIO, op.cit., pp.460-462; J. AUNESLUOMA, op.cit., pp.399-400.

17. J. AUNESLUOMA, op.cit., pp.203-204 and 388-390. 
positive, but it was noted that the key issue was to strengthen trade relations, not to participate in the political integration of Europe. ${ }^{18}$

This creates the starting point for further discussion, since the changing times suggested that the momentum for change of foreign policy approach existed. There are two main notions: first, the Finnish dominant long-term foreign policy discourse emphasized that there was no need to apply for membership mainly to avoid any indication that Finland was relinquishing its non-aligned status; and secondly, the economic discourse started to increasingly address the need to move Finland closer to the Western European integration process. These two notions clashed with the changed international discursive context.

Since 1986, the Soviet Union had shifted its position towards the Council of Europe. The relations between the various Socialist countries and the Council were increasingly improving in the era of Mikhail Gorbachev. Hungary stressed the need to improve relations to the Council and frequent contacts had been made. For Finland this meant that if the country was to try to join the Council, it was possible that the Soviet Union would not try to refer to the existence of the YYA Treaty and oppose Finland's accession. Furthermore, the representatives of the Council had been active towards Finland; in 1987 the representatives of the Council had informed the Finnish diplomats about strengthening Eastern relations and viewed the potential Finnish membership favourably. ${ }^{19}$

In summer 1987 the increasing domestic discussion led to a new deliberation within the Finnish government. The Minister for Foreign Affairs Kalevi Sorsa (SDP) had told President Koivisto at the end of May about an increasing parliamentary pressure to join the Council of Europe. ${ }^{20}$ The ministry's officials also emphasized a more economy-oriented reason; the political department within the ministry of Foreign Affairs argued that the most essential argument for Finnish membership was the need to improve Finland's 'image' in foreign affairs, since Finland's current position in relation to the Council of Europe occasionally caused speculation and occasionally its position had been considered difficult to understand. Matti Kahiluoto, head of political department, noted in June 1987 that there was no explicit reason why Finland should continue to stay out of the Council but considered that perhaps the issue could be returned to after the coming presidential elections scheduled for early $1988 .{ }^{21} \mathrm{In}$ the government's Foreign Affairs Committee the topic was subsequently discussed and it was decided that nothing had occurred to change the traditional position. ${ }^{22}$

18. EDUSKUNTA, Pöytäkirjat 1, Istunnot 1-41, 2.4.-25.9.1987. Valtiopäivät 1987, Valtion painatuskeskus, Helsinki, 1988, p.709; EDUSKUNTA, Asiakirjat E2, Toivomusaloitteet 1-771. Valtiopäivät 1987, Valtion painatuskeskus, Helsinki, 1987, pp.65-66; Iltalehti, 20.05.1987; Kauppalehti, 20.05.1987; Uusi Suomi, 20.05.1987; Nykypäivä, 21.05.1987.

19. AMFA, Box 13.0 EN, Murto, 28-30.09.1987.

20. M. KOIVISTO, Historian Tekijät. Kaksi Kautta II, Kirjayhtymä, Helsinki, 1995, p.279.

21. AMFA, Box Cb VN:n ulkoasiainvaliokunnan pöytäkirjat 1987, Muistio 510, 03.06.1987.

22. AMFA, Box Cb VN:n ulkoasiainvaliokunnan pöytäkirjat 1987, Pöytäkirja 09.06.1987. 
The ministry's political department took the view that although the matter was clearly raising new interest, economic integration needed more attention. Juhani Suomi, a Finnish historian, concluded that President Koivisto had shifted his position due to a similar change of attitude within the government, and most likely wanted to exploit the topic in the coming elections. ${ }^{23}$ Furthermore, there was not really enough [political] 'capital' to promote Finnish membership of the Council as one official, Risto Veltheim, noted. ${ }^{24}$ Nevertheless, the discussion on membership had begun, and this discussion was even viewed as a positive broadening of the traditionally inclusive foreign policy decision-making. ${ }^{25}$

Nevertheless the Council of Europe was not taken to represent an economic aspect of European integration, but rather to represent a step towards embracing certain Western common values. However, the entire value discussion was mostly absent, besides the acknowledgement that the human rights aspect was important; membership of the Council was perceived as a pragmatic way to enhance the image Finland projected of itself to the rest of Europe.

\section{A change in the presidential discourse leads to a turn: reactions and practical issues}

Membership was nevertheless set aside until after the presidential elections at the end of January 1988. As such, it was somewhat surprising, at least for the general public, that the incumbent President Mauno Koivisto, formerly a Social Democrat Prime Minister, decided to politicise the issue during his campaign for re-election and said that the membership could be reconsidered in near future. The statement received attention also because not only was there a presidential election imminent, but Koivisto had also rejected full membership in December 1987.26 The tactical nature of the move was underlined by the fact that Koivisto used the opportunity to stress the nation-wide audience; on the same day he had given an interview to a newspaper with a significantly smaller outreach, and at that time maintained a calmer position on Finnish membership. It was a response to a threat from the political centre. One week earlier, in an interview for the quality daily Helsingin Sanomat, the Finnish Centre Party's presidential candidate, Paavo Väyrynen, had proposed that Finland should seek full membership in the future, calling the current relationship 'unnatural'. This was later interpreted to have influenced not only Koivisto's change of mind, but also to have prompted a similar reaction from another presidential candidate, Harri

23. J. SUOMI, op.cit., p.336.

24. AMFA, Box UN 13.01987 I, Muistio, 17.08.1987.

25. M. JAKOBSON, Kuka saa puhua Euroopan neuvostosta?, in: Suomen Kuvalehti, 21.08.1987, p.30.

26. Helsingin Sanomat, 27.01.1988. 
Holkeri (National Coalition Party, NC) ${ }^{27}$ Because of that Koivisto's statement was widely regarded as surprising among officials and politicians - also in the ministry of Foreign Affairs - and interpreted to be related to the election campaigning. ${ }^{28}$

After Koivisto's remarks, there was a sudden shift in the atmosphere. The role of the President in the exercise of foreign policy had been a dominant feature for years, and as such, the President's changed position influenced different sides of the political field. For instance, the conservative Minister for Foreign Trade Pertti Salolainen (NC) quickly changed his position. ${ }^{29}$ Salolainen's remarks were noted in the left-wing newspaper Kansan Uutiset; it appeared that the paper understood the Finnish desire to 'Westernise' its foreign image despite the fact that the Council of Europe was a product of the Cold War. ${ }^{30}$ Support for Koivisto's changed stance was not universal. Another presidential candidate, Kalevi Kivistö, who represented leftist party Democratic League of the Finnish People, warned of endangering Finnish national selfdetermination by joining the Council instead of considering wider European co-operation. ${ }^{31}$ Mauno Koivisto duly won the election and started his second term as the President on 1 March 1988.

The ministry had started to work with the issue after Koivisto's public comment. Matti Kahiluoto proposed in a memorandum on 8 April 1988 that Finland should apply for membership; one of the reasons was the discussion on the Finnish 'image' in international relations that had raised critical questions in different situations. Furthermore, the political significance of the Council was deemed rather symbolic in politicians' comments..$^{32}$ This indicated an interest in presenting the membership with a low a profile as possible. In the West and North of Europe the Finnish plans were viewed positively; this happened, for instance, in Denmark. ${ }^{33}$ The officials of the Council had likewise noted the positive discussion regarding Finland's membership and the Secretary General of the Council of Europe, Marcelino Oreja, was willing to make an unofficial visit to Finland. ${ }^{34}$

The government continued to align itself behind Koivisto's new position, as the Soviet Union had not rejected the Finnish membership, considering the decision as one for the Finns themselves. On Friday 22 April 1988 President Koivisto and the government's Foreign Affairs Committee officially decided to start negotiations with

27. U. HÄMÄLÄINEN, P. VÄISÄNEN, Paavo Väyrynen luottaa taas omiin voimiinsa, in: Helsingin Sanomat, 19.01.1988, p.13; U. HÄMÄLÄINEN, T. OVASKA, Lännettymisen Lyhyt Historia, WSOY, Porvoo, Helsinki and Juva, 1988, p.27.

28. Helsingin Sanomat, 28.01.1988.

29. Turun Sanomat, 12.06.1987; M. LAAPOLA, Aika on kypsä Suomen jäsenyydelle, in: Uusi Suomi, 28.01.1988.

30. T. KARI, Euroopan neuvosto on blokkiajattelun tuote, in: Kansan Uutiset, 28.01.1988.

31. K. HIRVASNORO, Kivistö vaatii Suomea panostamaan yleiseurooppalaiseen yhteistyöhön, in: Kansan Uutiset, 28.01.1988.

32. AMFA, Box 32.00 EN 1988 I, Kahiluoto, 08.04.1988.

33. AMFA, Box 32.00 EN 1988 I, Kööpenhamina ulkoasiainministeriölle, 28.04.1988.

34. AMFA, Box 32.00 EN 1988 I, Salasanoma Pariisista ulkoasiainministeriölle, 04.02.1988. 
the Council of Europe about possible Finnish membership. ${ }^{35}$ President Koivisto apparently divided the political integration into hard and soft parts; full membership of EFTA represented the hard part and was more difficult. As such, membership of the Council of Europe represented the soft side of the co-operation and Koivisto felt disinclined to handle the soft side because it could result in problems with the hard side. He nevertheless had, in his own words, thought that "we would proceed slowly, but nevertheless proceed we would' (Original in Finnish: 'liikkeelle lähdettäisiin hitaasti, mutta lähdettäisiinpä kuitenkin'). ${ }^{36}$

The issue did not receive immediate attention in Parliament. Outside the plenary hall, on the other hand, Arvo Aalto, chairman of the Communist Party of Finland $(\mathrm{CPF})$, immediately turned down the government's decision as a way to reduce Finnish neutrality. The leftist newspaper also dubbed the membership 'Westernisation', like Finland's EFTA membership, fearing a loss of national sovereignty. ${ }^{37}$ Several other newspapers were on the other hand positive towards membership; the quality periodical Suomen Kuvalehti considered the lack of stir in political discussions unsurprising and called for new advances in relations to the EC after accession to the Council of Europe. ${ }^{38}$ Other party leaders supported membership and it was generally perceived that the decision to join the Council would not alter the long-term foreign policy position despite the claims by the CPF chairman. ${ }^{39}$

What had happened was that the changes in discourse at the top level in Finnish foreign policy immediately led to an impact on other political forums. This was not surprising given the strong position of the President not only in constitutional terms but as a most prominent figure in Finnish foreign policy. As most of the parties were in favour of membership, the domestic political forum was ready to employ a similar change of discourse. This was proof of major presidential influence in the Finnish foreign policy discussions.

As a counter-argument against leftist fears of loss of sovereignty, Harri Holkeri (NC), the Finnish Prime Minister, insisted that membership would not harm the longterm policy of neutrality and urged forging stronger cultural ties to Europe. ${ }^{40}$ Yrjö Hakanen, the chairman of the Communist Party of Finland - Unity (CPFu), had said that Finland should not join the Council before the Council would accept the Socialist

35. The Committee consisted of the following persons: President Mauno Koivisto, Prime Minister Harri Holkeri, Minister for Foreign Affairs Kalevi Sorsa, Minister for Education Christopher Taxell, Minister for Transport Pekka Vennamo and Minister of the Treasury Erkki Liikanen, Minister for Trade and Industry Ilkka Suominen. Matti Kahiluoto, an official within the ministry of Foreign Affairs, acted as secretary during the meeting on 22 April 1988.

36. AMFA, Box Cb VN:n ulkoasiainvaliokunnan pöytäkirjat v. 1988, Pöytäkirja, 22.01.1988; Box 32.001988 I, Lehdistötiedote, 22.04.1988; Helsingin Sanomat, 23.04.1988; Uusi Suomi, 23.04.1988; Kansan Uutiset, 23.04.1988; M. KOIVISTO, op.cit., p.280.

37. Kansan Uutiset, 23.04.1988 and 26.04.1988.

38. E.g., Uusi Suomi, 24.04.1988; Helsingin Sanomat, 24.04.1988; Turun Sanomat, 23.04.1988; EteläSuomen Sanomat, 24.04.1988; Suomen Kuvalehti, 29.04.1988.

39. Helsingin Sanomat, 23.04.1988.

40. A. HEINONEN, A and T. KARI, Holkeri on tyytyväinen itseensä ja hallitukseen, in: Kansan Uutiset, 30.04.1988. 
states as members and the one should strengthen the Finnish human rights policy with better employment measures and other domestic policies. ${ }^{41}$ The idea of first making the Council's core values as pan-European as possible also started to emerge in the left-wing discourse. It appeared that the political discourse among the more radical left noted the apparently broad support for membership but tried to reflect own ideas as much as possible.

Generally speaking, the pan-European discourse was a part of the pro-Soviet vocabulary. The Finnish left-wing political sphere had disintegrated in 1986. As a whole, this side of the political spectrum entailed various groups, only some present in Parliament; $\mathrm{CPFu}$, the Communist Party of Finland, the Democratic League of the Finnish People (DLFP) and the Democratic Alternative (DA). Despite ideological differences, attitudes towards membership of the Council of Europe were similar in the various left-wing factions, as general convergence with the West was criticised. Furthermore, different left-wing groups shared the use of the pan-European vocabulary that linked the policy to the YYA Treaty. ${ }^{42}$ Given that the Socialist political groups had a significant influence in the domestic political sphere, it was not surprising that the pan-European theme became important; if not employed, other options to portray the membership as an erroneous solution were limited.

In the parliamentary forum the decision-making drew criticism when the Foreign Affairs Committee studied the government's report on its foreign policy activities in 1987. The Committee issued a memorandum in early May 1988 and two leftist members, Jarmo Wahlström, who was chairman of the CPF but representing the DLFP in Parliament, and Ensio Laine (DA), objected to the government's Foreign Affairs Committee decision to start membership negotiations with the Council of Europe on the grounds that it was carried out with wrong procedure and contrary to the system of government. Otherwise the Foreign Affairs Committee had approved the government's intention to seek membership of the Council. ${ }^{43}$

The Council of Europe reacted positively on Finnish membership. On 27 May 1988, after a series of negotiations, it was announced that Finland would be invited to become a full member of the Council of Europe; the formal procedure of the Council stated that the Council would invite states as members instead of states applying for membership directly. ${ }^{44}$ Simultaneously Finland stated that it was ready to embrace "the principles of the Council of Europe as laid down in Art. 3 of the Statute and is willing to collaborate in the realisation of the aim of the Council'. ${ }^{45}$

41. Tiedonantaja, 26.04.1988.

42. E.g. DEMOKRAATTINEN VAIHTOEHTO, Demokraattisen Vaihtoehdon vaaliohjelma 1987, Demokraattinen Vaihtoehto, 1987. Available at: http://www.fsd.uta.fi/pohtiva/ohjelma?tunniste $=$ devavaali1987 (accessed 21 April 2015).

43. EDUSKUNTA, Asiakirjat C1, Valiokuntien mietinnöt ja lausunnot.Valtiopäivät 1988, Valtion painatuskeskus, Helsinki, 1989, ulkoasiainvaliokunnan mietintö no.8.

44. AMFA, Box 32.00 EN 1988 II, Lehdistötiedote, 27.05.1988.

45. AMFA, Box 32.00 EN 1988 II, Sorsa to Oreja, 27.05.1988. 
In Parliament membership of the Council now attracted criticism and support, the latter being the dominant feature. However, Parliament was also ready to address membership and as the Speaker Matti Ahde (SDP) noted in June 1988, European integration was one thing among many other foreign policy themes that had clearly started to arouse interest in Parliament, a feature rather new in Finnish foreign policy. ${ }^{46}$ This hinted a possibility of a change in the Finnish discursive context, and a potential for parliamentarisation, a phenomenon that would not be surprising since the foreign policy parliamentary debates had become increasingly challenging to the executive power, for instance in Britain in the $20^{\text {th }}$ century. ${ }^{47}$ This, however, had little impact on the parliamentary aspect.

Generally speaking, the Parliament of Finland discussed membership of the Council of Europe and the idea of the values it represented in a rather 'West European' way; their existence was not contested and the debate concentrated on pragmatic issues, for instance on the question of harmonising the Finnish legislation with human rights and to the ideological rift between politicians. Furthermore, the way in which the government had suddenly taken a new kind of decision without first discussing the matter with Parliament drew criticism. ${ }^{48}$ The common understanding of democracy was present. During one debate at the end of May 1988, Ensio Laine, one of the dissidents in the Foreign Affairs Committee, criticised the 'superficial' handling of Parliament's Foreign Affairs Committee that, according to him, resulted in a de facto expression of support for membership of the Council. ${ }^{49}$ The critical attention given to human rights may sound surprising, but in the context of the 1980s it was not; Finland strongly emphasized the Organisation for Security and Cooperation in Europe (OSCE), a process that had started in Helsinki in 1975 and which stressed the human rights aspect, but which was also accepted by the Soviet Union. This gave the leftist MPs a chance to utilise arguments related to the pro-Soviet approach. Accusations of 'Westernisation' belonged to a similar political vocabulary employed to endorse the pro-Soviet line.

In the only vote that concerned attitudes towards membership, Wahlström and Laine tried to criticise the overall positive attitudes towards membership through a vote, but with no success. Parliament rejected their motion by 143 votes to 15 , with 41 abstentions. This indicated significant and broad parliamentary support for membership, sparked by the President's individual comment during an election campaign. Johannes Virolainen MP (CP) even pointed out later that although he personally was not enthusiastic about membership of the Council of Europe, he was ready to trust

46. M. AHDE, Parlamentarismi ja ulkopolitiikka. Esitelmä Paasivi-Seurojen neuvottelukunnan kokouksessa Oulussa 20.6.1988, Paasikivi-Seuran monistesarja nro 78, Paasikivi-Seura, Helsinki, 1988, p.3.

47. P. IHALAINEN, S. MATIKAINEN, The British Parliament and Foreign Policy in the $20^{\text {th }}$ Century: Towards Increasing Parliamentarisation?, in: Parliamentary History, 1(2016), pp.1-14.

48. EDUSKUNTA, Pöytäkirjat 2, Istunnot 39-77, 19.4-14.6.1988. Valtiopäivät 1988, Valtion painatuskeskus, Helsinki, 1989, pp.1657-1659, Alho and Männistö; pp.1660-1661, Männistö; p.1664, Jäätteenmäki.

49. Ibid., pp.1674-1675 Ahlgren; pp.1671-1672, Laine. 
the President and the government in this matter and recommended that Parliament take a similar position and carry on preparing for membership. This membership, however, represented the final step before more caution was needed as the political integration to Europe would move closer. ${ }^{50}$

\section{Accession proceeds}

The accession process continued at quite a rapid pace within the ministry of Foreign Affairs. In their own examination, the preparatory group of officials confirmed the reduced political role of the Council, and improved opportunities for co-operation with the Socialist countries. Interestingly the EC was seen as a direct rival to the Council; this development, however, had clearly helped to present the Council as a more politically neutral organisation. ${ }^{51}$

A group of Finnish parliamentarians representing different parties visited Strasbourg in September 1988 and the human rights aspect was prominent in the discussions. ${ }^{52}$ For the Council's officials, the positions of the Finnish main parliamentary parties were important, and consultations were held during the visit about attitudes in general. In the discussions between the leading rapporteur Friedrich Probst and a group of Finnish parliamentarians, 'the general feeling was that Finland had too long been absent from the family table'. The documents reveal that even the two Socialist members (most likely indicating Esko-Juhani Tennilä (DA) and Esko Seppänen) representing two different leftist parties had appeared to be satisfied with the information that the sovereignty of Finland would not be undermined by membership. ${ }^{53}$ In the meeting, a first term Esko Seppänen MP (DLFP) had expressed fears about a possible Finnish further alignment towards the EC; he also asked Marcelino Oreja, the Secretary-General, whether a more pan-European co-operation organisation, like that proposed to Oreja by General Wojciech Jaruzelski of Poland, should be established. Oreja rejected this idea in terms of it leading to an unwanted change in the Council's values. ${ }^{54}$ The leftist MPs were able to discuss the idea of a more panEuropean Council in different forums, but if the membership had strong supportive consensus, the actual effort to directly influence the values was non-existent. In public this discussion was not reported.

The Council seemed to emphasize its Western-oriented value position, but on the other hand the Finnish officials were quite open about the communist influence and the Finnish ability to apply for membership. One official told rapporteurs, who were a group of Council representatives assigned to study Finland's eligibility, that the

50. Ibid., pp.1792; pp.1933-1934 Virolainen.

51. See AMFA, Box 32.00 EN 1988 III, Pöytäkirja 08.06.1988.

52. AMFA, Box 32.00 EN 1988 III, Muistio 658, 31.08.1988.

53. AMFA, Box 32.00 EN 1988 IV, Oslo ulkoasiainministeriölle, 14.09.1988.

54. Ibid., Muistio 689, 12.09.1988. 
Communist Party in Finland had weakened and this helped to create broad parliamentary support for membership. As for the Council's opinion, during a conversation with Minister for Foreign Affairs Sorsa, Harald U. Lied, one of the rapporteurs, rejected the idea of having Socialist countries as members despite the improved cooperation with them. Why? Because the understanding of democracy was simply too different. ${ }^{55}$ This indicated that the Council was not willing to completely relinquish its political aspect.

The Council of Europe's different bodies, the Parliamentary Assembly and the Committee of Ministers unanimously approved Finnish membership on 1 February 1989. Finland was expected to join the organisation on 5 May 1989, on the 40th anniversary of the founding of the organisation. It is important to remember that Council representatives had been active at the diplomatic level, giving a positive signal. ${ }^{56}$ The report of the rapporteurs was overwhelmingly positive; not only were the Council's requirements met but the Finnish 'spirit of internationalism' was noted and applauded. The Conservative Lied, one of the rapporteurs, estimated that the acclamation was the only appropriate response to Finland; an issue that would remove 'a longstanding anomaly' from the Council. Finland was simply a part of the 'European democratic area' ${ }^{57}$ In the session of the Parliamentary Assembly Finland' membership was approved unreservedly after a brief discussion.

John Wilkinson (Conservative), a British representative, noted that Finland 'wholly fulfils the strict criterion of our organisation which we rightly so jealously preserve'. Wilkinson viewed the Finnish accession as a sign of better times in terms of plural democracy in Eastern Europe. As the Council of Europe and its current presidency represented 'the evangelist of democratic ideals and the rights of man...', the behaviour of the USSR, for instance the fact that it had not invoked the Agreement of Friendship, Cooperation, and Mutual Assistance in case of Finnish accession, seemed to suggest that times were changing. Finland, furthermore, seemed to be an ideal member state, especially in terms of human rights. Even though Finland was a neutral country, it was still committed both to human rights and to the democratic tradition of Europe. It appeared that the Finnish membership application was, above all, an indication of success for the Western political sphere. There was no discussion regarding the Finnish domestic political sphere; the values of the Council were there to be embraced instead of analysing the potential need for a review. ${ }^{58}$

On the Finnish side, President Koivisto was able to inform Parliament at the opening ceremony of the new Diet on 3 February 1989 that Finland was about to join the Council of Europe; this appeared as just another issue during fundamental changes

55. Ibid., Muistio 825, 28.08.1988; Liite muistioon 825, 27.08.1988.

56. AMFA, Box 13.0 EN, Murto, 28.09-30.09.1987.

57. AMFA, Box 32.00 EN 1988 V, Council of Europe. Parliamentary Assembly. Report on the application for membership by Finland, 22.12.1988.

58. COUNCIL OF EUROPE, Parliamentary Assembly. Fortieth Ordinary Session. Official Report. Twenty-first Sitting, Wednesday 1 February 1989 at 10 am, Council of Europe, Strasbourg, 1989, cols.4-29, 132-144. 
in Eastern Europe ${ }^{59}$ Koivisto's comment regarding membership indicated how the membership application was handled with very limited parliamentary process. In 1988 Parliament had debated the issue briefly in relation to broader foreign policy issues, but the policy to join the Council as a single and only topic had not been introduced for debate; Parliament would have its opportunity to stress the policy later in spring, but it was evident that its approval would only provide the 'rubber stamp'.

The leftist MPs continued to address the wider pan-European 'option', although the actual question of how a pan-European organisation could be formed without Finland first entering the Council remained unclear. For instance, MP Esko Seppänen tried to insert a clause into one government motion featuring policy towards the Council of Europe which would have entailed an obligation to advance broader panEuropean co-operation should Finland join the Council of Europe, but this motion was voted down. ${ }^{60}$ Within the political left wing, there was also support: DLFP approved the membership, limiting the amount of opposition. ${ }^{61}$

Nevertheless, the government presented its motion to have Finland join the Council of Europe to President Koivisto on 3 March 1989. The motion emphasized the Council as a forum to strengthen pluralism and relations other than ones dealing with trade. ${ }^{62}$ On the same day the government motion was presented to Parliament. The MPs debated the motion on 8 March 1989. Ensio Laine (DA) was the only representative to oppose the Finnish entry into the Council; he considered the Council to be linked to the political blocs and dominated by NATO and the EC countries. ${ }^{63}$

Prime Minister Holkeri (NC) insisted that membership would not mean integration into Western Europe, an issue clearly considered important, and emphasized that entry would not mean a loss of Finnish sovereignty or the loss of Finland's long-term foreign policy position. The schedule was tight and the parliamentary process had to be quick; Ensio Laine's aim, articulated in Parliament, to postpone the handling of entry until the Finnish translation of the Convention on Human Rights, missing due to lack of time, would become available, was bypassed with the government's procedural manoeuvre. ${ }^{64}$ The report by the newspaper Etelä-Suomen Sanomat did not speak well for Parliament's abilities to exercise foreign policy decision-making; the government had given the motion to Parliament's Foreign Affairs Committee, and it 'had to hurry up' since it was already decided that Finland would join the Council in May. ${ }^{65}$ This was a fairly well-grounded interpretation, as the process seemed to be so rapid that Parliament played only a minor role.

59. EDUSKUNTA, Pöytäkirjat 1, Istunnot 1-38, 1.2.-14.4.1989. Valtiopäivät 1989, Valtion painatuskeskus, Helsinki, 1989c, p.22.

60. EDUSKUNTA, Pöytäkirjat 1..., op.cit., pp.181-182, Seppänen.

61. SKDL, Vasemmisto liikkeellä. SKDL 15. liittokokous 20--22.5.1988 Turku, SKDL, Helsinki, 1988, p.17.

62. AMFA, Box 32.00 EN 1989 I, Esittelylista, liite 002, 03.03.1989.

63. EDUSKUNTA, Pöytäkirjat 1..., op.cit., pp.688-690, Laine.

64. Ibid., p.683, Laine.

65. Ibid., pp.676-677, Holkeri; Etelä-Suomen Sanomat, 09.03.1989. 
To sum up, given that the government motion had included the Finnish translation of the statute of the Council of Europe, it was interesting that the Statute's phrase 'spiritual and moral values that are the common heritage of their peoples' was taken somewhat for granted in the Parliament of Finland; as been discussed in media, in politics and within the Council of Europe, Finland had met the requirements for some time already ${ }^{66}$ The Finnish MPs considered themselves representatives of true parliamentary democracy. The discussion on human rights also supported value principles similar to those the Council represented. Its underlying theme was the political value of including all European countries in one co-operative pan-European organisation; it expressed the value of working together to achieve common goals and to remove the borders but still to continue to uphold the distinct national cultural features. In this sense the Finnish accession to an international organisation cannot be perceived as a way to increase democratisation, as has been argued to be the case among many other nations seeking membership of an international organisation. ${ }^{67}$

On 18 April 1989 the Parliament of Finland agreed to join the Council; 121 MPs voted in favour and four voted against, all of them representing the Democratic Alternative party. More surprising was the fact that 74 MPs were absent, portraying uneasiness with the perhaps too rapid desire to join the organisation, despite the known challenges to the Finnish legislation. The decision was not just about joining an organisation. As Ilkka-Christian Björklund (SDP), one of the newly elected Finnish representatives to the Parliamentary Assembly, noted, European integration as a whole was a means to strengthen the European identity and the economy in the face of worldwide competition. The Council was linked to the tools to nurture that identity but also it played an important role in relation to the European Community, an organisation with considerable influence over European trade. ${ }^{68}$ Finland joined the Council of Europe on 5 May 1989. Otherwise the Finnish MPs were adjusted to the Council's tradition in terms of values, as could be expected, since the domestic discussion did not challenge the core values.

\section{Conclusion}

The Finnish historical evidence gives reason to argue that the value-related political discussion was an underlying theme when deciding on joining the Council of Europe; the Finns felt confident that their political system was compatible with the Council, but it was more important to avoid domestic political turmoil by rejecting any possible sign of further European political and economic integration. This was achieved by emphasizing more preferred issues such as a change in the times, the role of cultural

66. EDUSKUNTA, Asiakirjat A1. Hallituksen ..., op.cit., HE no: 17, p.15.

67. E.D. MANSFIELD, J.C. PEVEHOUSE, Democratization and International Organizations, in: International Organization, 1(2006), pp.137-167.

68. EDUSKUNTA, Pöytäkirjat 1..., op.cit., pp.1085-1086, Björklund. 
co-operation instead of 'hard issues' and the encouragement of issues the domestic left-wing politicians deemed important, notably the rhetorical desire to broaden the Council's scope of membership. If economic co-operation was pursued in other arenas, membership of the Council of Europe represented an ideological step of moving closer to the West. All in all, the Finnish case illustrates how a nation under different international and domestic pressures comes to an agreement on a change in foreign policy tradition. In this case it was a combination of an opportunity to press ahead with the matter but at the same time to try to uphold the consensus-oriented approach. The process did entail an opening of the traditionally hidden foreign policy discussion, but the role of parliamentarisation continued to be a limited one in the early phase of the wider process that would take Finland towards European economic and political integration. 